\title{
Effects of roasting conditions on the physicochemical properties of Coffea arabica beans
}

\author{
Yeon-Soo Suh ${ }^{1}$, Seung-Heon Lee ${ }^{2}$, Yafang Shang ${ }^{3}$, Won-Jong Lee ${ }^{1 *}$ \\ ${ }^{1}$ Department of Food and Nutrition, Gangneung-Wonju National University, Gangneung 25457, Korea \\ ${ }^{2}$ Hak-san Co., Ltd., Gangneung 25623, Korea \\ ${ }^{3}$ Department of Chemical Engineering and Food Processing, Hefei University of Technology, \\ Xuancheng, Anhui Province 242000, China
}

\section{배전조건이 아라비카 커피의 이화학적 성질에 미치는 영향}

\author{
서연수 ${ }^{1} \cdot$ 이승헌 $^{2} \cdot$ 상아방 $^{3} \cdot$ 이원종 $^{1 *}$ \\ ${ }^{1}$ 강릉원주대학교 식품영양학과, ${ }^{2}$ (주)학산, ${ }^{3}$ 중국 허페이공과대학
}

\begin{abstract}
Effects of roasting on physical (weight, volume, density and color) and chemical properties (total phenol, caffeine, chlorogenic acid and antioxidant properties) of three Arabica coffee beans (Brazil Bourbon, Indonesia Mandheling and Kenya Tatu) were investigated. A steady weight loss, volume increase, and bean density decrease were observed during the roasting process. The $\mathbf{L}^{*}, \mathbf{a}^{*}$, and $\mathbf{b}^{*}$ values tended to decrease as the roasting temperature and time increased. Caffeine level was approximately $0.73 \%$ in green beans, and increased to $40-67 \%$ for darker roasts. Green beans contained the highest chlorogenic acid content, which decreased as the roasting temperature and time increased. The light- and medium-roasted coffee showed the highest total phenolol contents. The antioxidant activities were measured using DPPH and ABTS. The light-roasted coffee beans showed the highest antioxidant activities, and an approximately $36-51 \%$ loss in antioxidant activity was observed after further roasting. The flavor patterns of roasted coffee beans were analyzed using an electronic nose system based on gas chromatography. This analysis demonstrated that an electronic nose system can be applied to identify the green bean variety and the degree of roasting.
\end{abstract}

Key words : coffee, roasting, caffeine, chlorogenic acid, antioxidant properties

\section{서 론}

커피는 전 세계인들이 물 다음으로 많이 마시는 음료로, 전 세계 인구의 2/3가 커피를 마시고 있다(1). 세계 커피무역 에서 커피는 주로 커피를 볶은 전 상태인 생두(green been) 로 거래가 되며, 수입국에서 생두를 볶아 원두커피(roasted coffee)로 제조하게 된다. 커피의 생두는 탄수화물

*Corresponding author. E-mail : wonjlee@gwnu.ac.kr Phone : 82-33-640-2332, Fax : 82-33-647-9535

Received 3 June 2015; Revised 12 August 2015; Accepted 20 August 2015.

Copyright (c) The Korean Society of Food Preservation. All rights reserved.
(37 60\%), 지방(9 18\%), 단백질(11 13\%), 수분(10 13\%), 무기질(3.0 4.5\%)로 구성되어 있으며, 그 외에 카페인 (caffeine)과 클로로겐산(chlorogenic acid)이 중요한 성분으 로 알려져 있다(2).

커피 생두는 커피 고유의 향미를 느낄 수 없으며, 배전 (roasting)과정을 거쳐 커피 고유의 향미를 갖게 되기 때문에 배전 과정은 중요한 공정이라고 할 수 있다. 배전 과정 중에 Maillard 반응, Strecker 분해, 지방 분해, 당 분해 등 여러 반응이 일어나 유리 아미노산(amino acid)과 유리당(free sugar), 클로로겐산(chlorogenic acid), 트리고넬린(trigonelline) 등이 감소되며, 동시에 약 800 여 가지 이상의 화학물질이 생성된다(3). 배전 후 원두의 이화학적 성분은 생두의 종류, 배전 온도와 시간에 따라 달라진다. 
지금까지 수행된 커피 생두의 배전과 관련된 논문으로는 배전이 진행되는 중 향기성분의 변화(4), 배전 온도 및 시간 에 따른 향기성분 형성(5), 배전도 및 산지에 따른 유효 향기성분에 관한 연구(6), 배전조건이 항산화 특성에 미치 는 영향(7), 배전과정 중 변화되는 주요 화학성분에 대한 연구(8) 등이 있다.

커피는 항산화력이 있는 것으로 보고되고 있다. 커피의 페놀 함량은 레드와인보다 더 높은 것으로 보고되었으며 (9), 커피가 자유 라디칼과 바이러스의 감염을 예방하는 효과가 있다는 보고도 있으며(10), 커피의 섭취가 LDL-콜 레스테롤의 산화에 대한 감수성을 줄인다는 보고도 있다 (11). 배전 과정 중에 항산화물질의 함량의 변화에 대한 여러 연구가 행해졌지만 엇갈린 결과를 보이고 있다(12). Cho 등(7)은 배전 정도가 증가함에 따라 항산화력이 감소한 다고 보고한 반면, Suh 등(13)은 $165 ~ 185^{\circ} \mathrm{C}$ 에서 배전하였을 때에 온도 차이가 그리 크지 않아서인지 약배전한 시료와 강배전한 시료에서 페놀 함량, $\mathrm{DPPH}$ 와 $\mathrm{ABTS}$ 라디칼 소거 능에서 유의적인 차이를 나타내지 않았다고 보고하였다. 커피는 800 종 이상의 향기성분을 가진 가장 복잡한 식품 중의 하나로 풀질평가를 위해 전문 taster에 의한 cup-test나 훈련된 panel에 의한 관능평가가 일반적으로 수행되어 왔 다. Cup-test란 커피의 품질을 분류하기 위해서 커피농장이 나 생두 무역, 산업체 현장에서 많이 이용되는 평가방법이 지만 고도로 훈련된 sensory panel이 필요하다. $\mathrm{GC}$ 나 GC-MS가 커피의 휘발성 화합물의 분석에 이용되었으나 최근 보다 객관적이고 재현성 있는 커피의 품질평가를 위해 전자코를 이용하게 되었다(14).

본 연구에서는 3종류의 커피 생두를 배전 온도 181 21 $5^{\circ} \mathrm{C}$ 에서 약배전, 중배전, 강배전으로 볶아, 이에 따라 변화 되는 커피의 카페인, 클로로겐산, 총 페놀, 1,1-diphenyl2-picrylhydrazyl(DPPH)과 2,2'-anizo-bis(3-ethylbenzothiazoline-6-sulfonic acid)(ABTS) 라디칼 소거활성을 측정하여 배전강도에 따른 커피 구성성분의 변화를 조사하고자 하였 다. 또한 전자코를 이용하여 볶음 정도에 따른 커피의 향을 객관성 있게 분석하여 커피원두의 배전 정도를 예측할 수 있는 기초자료를 제시하고자 하였다.

\section{재료 및 방법}

\section{실험재료}

본 실험에 사용된 3종의 커피 생두는 브라질 미나스 제라 이스 주의 세라도 지역에서 생산된 버번 스페셜티(Brazil bourbon specialty, Cerrado, Brazil), 인도네시아 북 수마트라 지역에서 생산된 만델링 프리미엄(Indonesia mandheling premium G1, Tapanuli, Indonesia) 그리고 케냐 기암부 지역 에서 생산된 타투 스페셜티(Kenya AA tatu specialty,
Kiambu, Kenya)로 모두 2013년에 수확되어 수입된 Arabica 품종이었다.

\section{배전 및 분쇄}

커피 생두는 반열풍식인 후지로얄 샘플 로스터(Type R-002BZB, Fuji Coffee Machine Manufacture Co., Tokyo, $\mathrm{Japan}$ )를 이용하여 각각 $200 \mathrm{~g}$ 의 생두를 $180^{\circ} \mathrm{C}$ 에서 투입하 였다. 생두를 투입하면 드럼의 온도는 급격히 떨어진 다음 다시 온도가 올라간다. 온도가 올라감에 따라 생두의 색이 점차 갈색으로 변하면서 1차 균열(pop)에 도달한다. 그 후 일정 시간이 지나면 1 차 균열이 종료되며, 휴지기간을 거쳐 2 차 균열이 시작된다. 약배전은 1 차 균열이 시작하는 시점, 중배전은 1 차 균열이 끝나는 시점, 강배전은 2 차 균열이 시작하는 시점에서 배출하였다. 배출시간과 온도는 Table 1 과 같았다. 커피 생두 및 원두를 분석 바로 전에 커피 분쇄 기(Type R-220, Fujikouki Co., Ltd., Tokyo, Japan)를 사용하 여 $850 \mu \mathrm{m}$ (표준체 No. 20) 이하의 크기가 되도록 분쇄하여 사용하였다.

Table 1. Roasting conditions of green bean samples

\begin{tabular}{lcc}
\hline & Roasting time $(\mathrm{min})$ & Final temperature $\left({ }^{\circ} \mathrm{C}\right)$ \\
\hline Brazil & & \\
Light & 8.25 & 189 \\
Medium & 9.83 & 198 \\
Dark & 11.75 & 215 \\
\hline Indonesia & & \\
Light & 8.67 & 181 \\
Medium & 9.83 & 190 \\
Dark & 11.83 & 211 \\
\hline Kenya & & \\
Light & 8.15 & 185 \\
Medium & 9.75 & 195 \\
Dark & 11.67 & 215 \\
\hline
\end{tabular}

수분 함량, 중량 손실, 밀도, $\mathrm{pH}$

생두와 원두의 수분함량은 상압가열건조법(15)에 따라 시료 $1 \mathrm{~g}$ 을 $105^{\circ} \mathrm{C}$ 에서 5 회 반복하여 측정한 후 평균값으로 나타내었다.

총 중량손실은 생두를 볶기 전의 무게(WI)와 볶은 후의 무게 $(\mathrm{W})$ 를 정확히 측량하여 다음의 식으로 계산하였다.

$$
\text { 총 중량손실 }(\%)=\frac{(\mathrm{WI}-\mathrm{W})}{\mathrm{WI}} \times 100
$$

생두와 원두의 밀도는 $100 \mathrm{~mL}$ 눈금 실린더에 커피콩을 넣고 10 회 위아래로 흔들어 빈 공간을 최소화한 후 100 
$\mathrm{mL}$ 부피의 무게를 측정하였으며, 각 5 회 반복 측정하여 평균값을 계산하였다. $\mathrm{pH}$ 는 볶은 커피 $1 \mathrm{~g}$ 을 $100 \mathrm{~mL}$ 정용 플라스크에 넣고 $98^{\circ} \mathrm{C}$ 의 증류수 $100 \mathrm{~mL}$ 를 넣은 다음 20 분 동안 추출하여 여과한 액을 실온으로 식힌 후 $\mathrm{pH}$ meter(SP-701, Suntex Instruments Co., Ltd., Taipei, Taiwan) 를 이용해서 측정하였다.

\section{색도측정}

생두와 배전 조건 별 원두의 색도를 비교하기 위해 분쇄 한 시료를 색차계(CR-400, Minolta Camera Co., Ltd., Osaka, Japan)을 이용하여 5 회 반복 측정하여 그 평균값으로 하였 다. 색도는 명도 $\left(\mathrm{L}^{*}\right)$,적색도 $\left(\mathrm{a}^{*}\right)$,황색도 $\left(\mathrm{b}^{*}\right)$ 의 값으로 나타내 었다. 이 때 사용된 표준 백판의 $\mathrm{L}^{*}$ 값은 $95.99, \mathrm{a}^{*}$ 값은 -0.14 , $\mathrm{b}^{*}$ 값은 -0.24 이었다.

\section{카페인 및 클로로겐산 분석}

카페인 및 클로로겐산의 함량은 두 성분을 동시에 분석 할 수 있는 Hecimovic 등(16)의 방법에 따라 분석하였다. 커피 생두와 조건별로 배전한 커피 $2 \mathrm{~g}$ 을 정확히 평량하여 뜨거운 증류수 $\left(96^{\circ} \mathrm{C}\right) 20 \mathrm{~mL}$ 를 더한 후 15 분 동안 hot plate에 서 추출하였으며, 상온에서 냉각시킨 후 $0.45 \mu \mathrm{m}$ filter로 여과하여 최종 검체로 하였다. 분석기기로서는 Aglient 1200 HPLC system(Aglient Technologies, Palo Alto, CA, USA)을 사용하였고, column은 reverse-phase column Pinnacle C-18(Restek, Bellefonte, PA, USA) $(250 \times 4.6 \mathrm{~mm}$, $5 \mu \mathrm{m} \mathrm{id}$ )을 사용하였다. 이동상은 $1 \%$ formic acid(solvent A)와 HPLC grade methanol(solvent B)를 유속 $1 \mathrm{~mL} / \mathrm{min}$ 로 흘렸으며, $\mathrm{B}$ 용매의 비율을 $2 \%$ 에서 시작하여 20 분 후에 $32 \%, 30$ 분 후에 $40 \%, 40$ 분 후에 $95 \%$ 가 되게 하였다. 카페인 은 $278 \mathrm{~nm}$, 클로로겐산은 $330 \mathrm{~nm}$ 에서 측정하였다. 표준용 액 제조는 카페인과 클로로겐산(Sigma Aldrich Co., St. Louis, MO, USA)을 각각 $1,000 \mathrm{ppm}$ 으로 만든 다음 각각 $5,10,20,50 \mathrm{ppm}$ 으로 만들어 표준곡선을 작성한 다음 시료 에 대해서 농도를 측정하였다.

\section{총 페놀함량 측정}

추출물의 총 페놀함량은 Folin-Ciocalteu시약을 사용하여 측정하였다. 커피 추출물 $2 \mu \mathrm{L}$ 에 증류수 $78 \mu \mathrm{L}$ 를 첨가한 후 Folin-Ciocalteu phenol reagent(Sigma Aldrich Co., St. Louis, MO, USA) $20 \mu \mathrm{L}$ 를 각각 첨가하고 실온에서 5 분간 반응시켰다. 이 용액에 $20 \% \mathrm{Na}_{2} \mathrm{CO}_{3} 100 \mu \mathrm{L}$ 를 가한 후 암소 에서 30분 동안 방치한 후 Synergy HT-Multi-microplate reader(Bio- Tek Instrument, Winooski, VT, USA)를 이용하 여 $515 \mathrm{~nm}$ 에서 흡광도를 측정하였다. 총 페놀함량은 gallic $\operatorname{acid}(\mathrm{GA})$ 를 표준물질로 한 표준곡선에 의하여 산출하였다.

\section{$\mathrm{DPPH}$ 라디칼 소거활성 측정}

$\mathrm{DPPH}$ 라디칼 소거능은 Blois 방법(17)에 따라 측정하였
는데, 이는 자유 라디칼을 갖는 안정한 화합물인 $\mathrm{DPPH}$ 를 기질로서 항산화 활성을 측정하는 방법이다. 각 추출물 시 료를 2배 희석하여 96 well plate에 $20 \mu \mathrm{L}$ 부터 계열희석 분주하였고, $400 \mu \mathrm{L} \mathrm{DPPH}$ 용액 $180 \mu \mathrm{L}$ 를 넣고 혼합하여 암실에서 30 분간 반응시킨 후 $515 \mathrm{~nm}$ 에서 흡광도를 측정하 였다. 각 시료와 ascoric $\operatorname{acid}(\mathrm{AA})$ 의 DPPH 라디칼 소거능은 아래의 식에 의해 전자공여능으로 계산하였고, $50 \%$ 전자공 여능 값을 나타내는 SC50 값으로 표현하였다.

\section{전자공여능 $(\%)=(1-$ 시료의 흡광도 $/$ 무처리 흡광도 $) \times 100$}

DPPH 라디칼 소거능은 ascorbic acid equivalent(AAE)/g 건조 중량으로 표현하였다.

\section{ABTS 라디칼 소거능 측정}

$\mathrm{ABTS}$ 라디칼 소거능은 $\operatorname{Re}$ 등(18)의 방법에 따라 측정하 였다. ABTS 라디칼 용액은 $3.5 \mathrm{mM}$ potassium persulfate를 포함하는 $2 \mathrm{mM} \mathrm{ABTS}$ 용액을 8 배 희석시킨 후, 어두운 곳에 14 시간 보관하여 만들었다. 각 추출물 시료를 2 배 희석하여 96 well plate $20 \mu \mathrm{L}$ 부터 계열희석 분주하고, ABTS 라디칼 용약 $180 \mathrm{LL}$ 씩 가하였다. 상온에서 5 분간 반응 후, $730 \mathrm{~nm}$ 에 서 흡광도를 측정하였다. 각 시료의 ABTS 라디칼 소거능은 아래의 식에 의해 전자공여능으로 계산하였고, $50 \%$ 전자공 여능 값을 나타내는 $\mathrm{SC}_{50}$ 값으로 표현하였다.

\section{전자공여능 $(\%)=(1-$ 시료의 흡광도/무처리 흡광도 $) \times 100$}

ABTS 라디칼 소거능은 ascorbic acid equivalent(AAE)/g 건조 중량으로 표현하였다.

\section{전자코 분석}

배전 정도에 따른 차이를 GC-전자코로 분석하고자 하였 다. 커피분쇄기(Type R-220, Fujikouki Co., Ltd., Tokyo, Japan)를 사용하여 $850 \mu \mathrm{m}$ (표준체 No. 20) 이하의 크기가 되도록 분쇄한 시료 각 $1 \mathrm{~g}$ 이 들어 있는 vial을 $300 \mathrm{rpm}$ 으로 교반하면서 $60^{\circ} \mathrm{C}$ 를 유지하였고, 주입구 온도는 $130^{\circ} \mathrm{C}$ 인 상 태에서 주입하였다. 이 때 사용한 가스는 헬륨이었으며 분 당 $50 \mathrm{~mL}$ 의 유속으로 흘려보냈으며, 분석 시간은 5 분이었 다. Syringe purge는 3초를 유지한 후 thermostated tray holder에 놓은 후 head space syringe를 사용하여 $5 \mathrm{~mL}$ 을 취하였다. 시료는 자동시료채취기가 연결된 전자코 $(\mathrm{GC}$ type E Nose Heracles II, Alpha M.O.S., France)로 분석하였 다. 분석에 사용된 전자코는 두 개의 column $(100 \mu \mathrm{m}$ id \# $\mathrm{DB} 5,100 \mu \mathrm{m}$ id \#DB1701)과 두 개의 flame ionization detectors(FID)에 연결되어 있었다. 각 시료는 6회 반복을 실시하였다. 


\section{통계처리}

생두의 배전 조건에 따른 이화학적 평가 결과에 대해 시료간의 유의적 차이를 검사하기 위하여 분산분석 (analysis of variance, ANOVA)을 실시하였으며, 그 결과에 따라 $\mathrm{p}<0.05$ 수준에서 Duncan의 다중 범위 검정(Duncan's multiple range test)을 실시하였다.

\section{결과 및 고찰}

수분함량, 중량 감소, 부피 증가, 밀도, $\mathrm{pH}$

생두 및 원두의 수분함량, 중량 감소, 부피 증가, 밀도, $\mathrm{pH}$ 의 변화는 Table 2 와 같다. 본 실험에 사용된 커피는 모두 아라비카종으로 생두의 수분 함량은 브라질 버번이 $11.0 \%$ 로 가장 높았으며 인도네시아 만델링과 케냐 타투가 각각 $7.8 \%, 9.0 \%$ 로 나타났다. 커피의 수분 함량은 배전이 진행됨에 따라 급격히 감소되어, 배전 초기 $3.2 \sim 4.7 \%$ 에서 배전이 완료되었을 때는 $0.6 ~ 0.8 \%$ 까지 감소되었다. $\mathrm{Kim}$ 등(19)은 아라비카와 로부스타 품종의 생두 수분 함량은 8.5 10.3\%라고 보고하였으며, Tfouni 등(20)도 아라비카 품 종의 생두 수분함량이 8.5 9\%에서 배전 후에는 0.8 2.2\% 로 감소하였다고 보고하였다. Specialty Coffee Association of America(SCAA)에서는 스페셜티 생두의 적정 수분함량 을 내츄럴 커피의 경우 10 13\%, 워시드 커피의 경우는 $10 ~ 12 \%$ 로 규정하고 있으며, 생두의 수입과 보관 기준을

Table 2. Changes in weight, volume, density, moisture and $\mathrm{pH}$ of Arabica coffee beans during roasting

\begin{tabular}{lccccc}
\hline Coffee beans & $\begin{array}{c}\text { Moisture } \\
(\%)\end{array}$ & $\begin{array}{c}\text { Weight } \\
\text { loss (\%) }\end{array}$ & $\begin{array}{c}\text { Increased } \\
\text { volume }(\%)\end{array}$ & $\begin{array}{c}\text { Density } \\
(\mathrm{g} / \mathrm{mL})\end{array}$ & $\mathrm{pH}$ \\
\hline Brazil & & & & & \\
Green bean & $11.0 \pm 0.03^{\mathrm{a})}$ & 0 & 0 & $0.68 \pm 0.003^{\mathrm{a}}$ & - \\
Light & $2.5 \pm 0.36^{\mathrm{b}}$ & $11.2 \pm 0.58^{\mathrm{c}}$ & $52.4 \pm 1.04^{\mathrm{c}}$ & $0.39 \pm 0.002^{\mathrm{b}}$ & $5.2 \pm 0.02^{\mathrm{c}}$ \\
Medium & $1.6 \pm 0.10^{\mathrm{c}}$ & $14.5 \pm 0.50^{\mathrm{b}}$ & $64.5 \pm 0.35^{\mathrm{b}}$ & $0.35 \pm 0.003^{\mathrm{c}}$ & $5.3 \pm 0.01^{\mathrm{b}}$ \\
Dark & $0.6 \pm 0.01^{\mathrm{d}}$ & $18.5 \pm 0.50^{\mathrm{a}}$ & $77.9 \pm 0.95^{\mathrm{a}}$ & $0.29 \pm 0.000^{\mathrm{d}}$ & $5.7 \pm 0.01^{\mathrm{a}}$ \\
\hline Indonesia & & & & & \\
Green bean & $7.8 \pm 0.03^{\mathrm{a}}$ & 0 & 0 & $0.69 \pm 0.007^{\mathrm{a}}$ & - \\
Light & $3.7 \pm 0.06^{\mathrm{b}}$ & $11.2 \pm 0.29^{\mathrm{c}}$ & $38.6 \pm 0.64^{\mathrm{c}}$ & $0.43 \pm 0.006^{\mathrm{b}}$ & $4.9 \pm 0.01^{\mathrm{c}}$ \\
Medium & $2.3 \pm 0.05^{\mathrm{c}}$ & $14.5 \pm 0.00^{\mathrm{b}}$ & $56.3 \pm 0.85^{\mathrm{b}}$ & $0.37 \pm 0.004^{\mathrm{c}}$ & $4.9 \pm 0.01^{\mathrm{b}}$ \\
Dark & $0.8 \pm 0.05^{\mathrm{d}}$ & $18.3 \pm 0.29^{\mathrm{a}}$ & $76.8 \pm 0.00^{\mathrm{a}}$ & $0.31 \pm 0.004^{\mathrm{d}}$ & $5.4 \pm 0.01^{\mathrm{a}}$ \\
\hline Kenya & & & & & \\
Green bean & $9.0 \pm 0.08^{\mathrm{a}}$ & 0 & 0 & $0.72 \pm 0.006^{\mathrm{a}}$ & - \\
Light & $3.0 \pm 0.21^{\mathrm{b}}$ & $11.3 \pm 0.58^{\mathrm{c}}$ & $47.0 \pm 0.95^{\mathrm{c}}$ & $0.42 \pm 0.005^{\mathrm{b}}$ & $5.0 \pm 0.01^{\mathrm{c}}$ \\
Medium & $1.4 \pm 0.07^{\mathrm{c}}$ & $14.2 \pm 0.58^{\mathrm{b}}$ & $60.2 \pm 2.75^{\mathrm{b}}$ & $0.36 \pm 0.004^{\mathrm{c}}$ & $5.1 \pm 0.01^{\mathrm{b}}$ \\
Dark & $0.6 \pm 0.05^{\mathrm{d}}$ & $17.8 \pm 0.29^{\mathrm{a}}$ & $84.5 \pm 0.00^{\mathrm{a}}$ & $0.30 \pm 0.003^{\mathrm{d}}$ & $5.4 \pm 0.01^{\mathrm{a}}$ \\
\hline
\end{tabular}

${ }^{1)}$ Mean \pm standard deviation ( $\mathrm{n}=3$ ). Means in a column with same superscript letters are not significantly different $(\mathrm{p}<0.05)$.
제시하고 있는 International Coffee Organization(ICO)에서

는 8 10\%의 수분함량을 허용하고 있다(21).

커피의 배전 과정에서 중량 손실은 초기에는 주로 수분 손실에 기인하였다가 배전 말기에는 탄수화물 또는 minor 화합물들의 열분해 반응과 휘발성 물질들의 손실에 의한 것으로 보고되었다(22). 본 연구에서는 약배전 시 7.5 $10.0 \%$, 중배전 시 $14.5 \sim 15.0 \%$ 중량이 감소되었다가 배전 과정이 끝났을 때에는 브라질 버번, 인도네시아 만델링, 케냐 타투가 각각 $19.0 \%, 18.5 \%, 18.0 \%$ 의 중량 손실을 보였 다. 이는 Oosterveld 등(23)이 아라비카 품종을 약, 중, 강배 전했을 때 각각 $11 \%, 15 \%, 22 \%$ 의 중량이 손실되었다고 보고한 것이나 Franca 등(24)이 각각 7.5 10.0\%, 14.5 $15.0 \%, 18.0 ~ 19.0 \%$ 의 중량이 손실되었다는 보고와도 유사 한 것이었다. 배전에 의한 중량 감소와는 반대로 커피 원두 의 부피는 증가하는데 이는 열가공(배전) 과정에서 다공구 조 형성으로 인한 커피원두의 팽창에 의한 것이다(25). 배전 완료 시점에서 커피 생두 대비 76 87\%의 부피 증가를 보였 는데 이는 Jokanovic 등(25)의 48 50\%보다 다소 높은 값이 었다.

커피의 배전 중 밀도의 감소는 부피의 증가, 내부 가스의 생성, 열분해 반응, 휘발성분의 손실에 의한 중량감소에 의한 것으로 보고되었다(26). 중배전한 시료에서 케냐 타투 는 생두에 비해 $50 \%$, 브라질 버번은 $48.5 \%$, 인도네시아 만델링은 $46.4 \%$ 가 감소하였다 (Table 2). 이는 생두의 상태 에 따라 40 60\%의 감소를 보였다는 Franca 등(24)의 결과나 $35 ~ 44 \%$ 의 감소를 보였다는 Jokanovic 등(25)의 결과와 비 슷하였다. Alessandrini 등(22)은 Italian-style 배전수준에서 는 전형적으로 50 60\%의 밀도 감소를 보인다고 보고하였 다. Choi(27)는 일반적으로 밀도는 생두의 등급이 높을수록 크게 나타나며 같은 등급의 경우 가공법에 의해서는 차이가 없으며, 밀도가 높은 커피가 더 풍부한 향미를 가지며 배전 에 더 많은 시간이 소요되므로 배전 조건을 결정하는데 생두의 이해가 중요하다고 하였다.

커피의 배전 중 $\mathrm{pH}$ 의 변화는 약배전할 때 브라질 버번은 5.2 , 인도네시아 만델링은 4.9 , 케냐 타투가 5.0이었으며, 중배전, 강배전으로 갈수록 유의적인 차이를 보이며 증가 했다(Table 2). Illy 등(28)에 따르면 배전 강도에 따라 추출 한 커피의 $\mathrm{pH}$ 가 4.9 5.4이며, 내츄럴(natural) 커피가 워시드 (washed) 커피보다 $\mathrm{pH}$ 값이 더 높다고 하였는데, 이는 워시 드 커피가 점액질의 완전제거를 위해 발효과정을 거치기 때문이라고 하였다. 또한 원두커피의 $\mathrm{pH}$ 가 일반적으로 인 스턴트커피의 $\mathrm{pH}$ 보다 약간 높은 이유는 원두커피가 뜨거 운 상태로 공기 중에 노출되면서 다결정 구조의 산이 단결 정 구조의 산으로 변화되기 때문이라고 하였다(29). 커피원 두 추출물의 $\mathrm{H}^{+}$농도는 $\mathrm{CGA}$ 의 함량과 밀접한 관계가 있으 며, 강배전 시 $\mathrm{CGA}$ 의 함량감소로 $\mathrm{pH}$ 가 증가한다는 보고가 있는데(30), 본 연구에서도 배전이 진행될수록 $\mathrm{CQA}$ 의 함량 
이 감소하면서 $\mathrm{pH}$ 가 증가하는 경향을 나타냈다(Table 2).

\section{색 도}

$\mathrm{CIE}$ 체계로 측정한 커피 생두와 원두의 색도의 변화는 Table 3과 같다. 커피 생두의 $\mathrm{L}^{*}$ 값은 브라질 버번과 인도네 시아 만델링이 각각 57.1, 56.9이었으며, 케냐 타투가 67로 가장 밝게 나타났다. $\mathrm{a}^{*}$ 값은 적색과 녹색, $\mathrm{b}^{*}$ 값은 청색과 황색을 묘사하는 것으로 생두의 전형적인 green-yellow zone에서 약배전과 중배전 시 red-orange로 이동하였다가 배전 온도와 시간이 증가함에 따라 borwn zone으로 이동함 을 보여주었다. 배전이 진행됨에 따라 $\mathrm{L}^{*}$ 값과 유사하게 $\mathrm{a}^{*}$ 값과 $\mathrm{b}^{*}$ 값도 유의적으로 감소하여 커피원두는 균일한 갈 색이 되었으며, 이는 Alessandrini 등(22)의 결과와 비슷한 감소경향을 나타냈다. 배전 시 이러한 명도와 색상의 변화 는 열처리의 결과로 일어나는 Maillard 반응의 전형적인 결과로 이때 생성된 melanoidin과 같은 색소의 영향으로 보고되었다(31). 생두의 가공방식에 따라서는 워시드 (washed) 커피가 내추럴(natural) 커피보다 명도가 높게 나 타나는 것으로 보고되었는데, 이는 내추럴 커피가 커피체 리 상태로 건조되는 과정에서 체리의 당성분이 생두에 흡수 되기 때문에 명도가 낮아지는 것이라고 하였다(27). 커피원 두의 색도는 중량감소와 더불어 배전의 정도를 설계하는데 중요한 인자로 배전 중 클로로겐산의 함량 감소와도 깊은 상관관계가 있다고 보고되었다(27).

Table 3. Color values of green and roasted coffee beans samples

\begin{tabular}{lccc}
\hline & $\mathrm{L}^{*}$ & $\mathrm{a}^{*}$ & $\mathrm{~b}^{*}$ \\
\hline Brazil & & & \\
Green bean & $57.1 \pm 1.62^{\mathrm{a} 1)}$ & $8.44 \pm 0.31^{\mathrm{d}}$ & $22.58 \pm 0.87^{\mathrm{b}}$ \\
Light & $27.1 \pm 1.25^{\mathrm{b}}$ & $16.19 \pm 0.50^{\mathrm{a}}$ & $28.59 \pm 0.42^{\mathrm{a}}$ \\
Medium & $17.3 \pm 0.83^{\mathrm{c}}$ & $14.36 \pm 0.27^{\mathrm{b}}$ & $20.60 \pm 0.42^{\mathrm{c}}$ \\
Dark & $10.0 \pm 0.87^{\mathrm{d}}$ & $9.58 \pm 0.06^{\mathrm{c}}$ & $10.02 \pm 0.28^{\mathrm{d}}$ \\
\hline Indonesia & & & \\
Green bean & $56.9 \pm 1.59^{\mathrm{a}}$ & $7.32 \pm 0.21^{\mathrm{d}}$ & $19.53 \pm 0.45^{\mathrm{c}}$ \\
Light & $31.2 \pm 0.67^{\mathrm{b}}$ & $17.10 \pm 0.11^{\mathrm{a}}$ & $28.66 \pm 0.15^{\mathrm{a}}$ \\
Medium & $21.1 \pm 1.05^{\mathrm{c}}$ & $14.69 \pm 0.30^{\mathrm{b}}$ & $22.72 \pm 0.50^{\mathrm{b}}$ \\
Dark & $9.2 \pm 1.02^{\mathrm{d}}$ & $10.67 \pm 0.32^{\mathrm{c}}$ & $11.65 \pm 0.64^{\mathrm{d}}$ \\
\hline Kenya & & & \\
Green bean & $67.0 \pm 0.53^{\mathrm{a}}$ & $5.34 \pm 0.12^{\mathrm{d}}$ & $16.53 \pm 0.29^{\mathrm{c}}$ \\
Light & $28.0 \pm 0.48^{\mathrm{b}}$ & $16.61 \pm 0.09^{\mathrm{a}}$ & $25.82 \pm 0.57^{\mathrm{a}}$ \\
Medium & $20.0 \pm 0.55^{\mathrm{c}}$ & $13.86 \pm 0.16^{\mathrm{b}}$ & $18.43 \pm 0.11^{\mathrm{b}}$ \\
Dark & $10.3 \pm 0.77^{\mathrm{d}}$ & $9.85 \pm 0.22^{\mathrm{c}}$ & $10.64 \pm 0.35^{\mathrm{d}}$ \\
\hline
\end{tabular}
${ }^{1)}$ Mean \pm standard deviation $(\mathrm{n}=5)$. Means in a column with same superscript letters
are not significantly different $(\mathrm{p}<0.05)$.

\section{Caffeine 함량}

품종별 커피 생두와 원두의 배전 정도에 따른 카페인
함량은 Table 4와 같다. 브라질 버번과 인도네시아 만델링 에서 생두는 각각 $7.4 \mathrm{mg} / \mathrm{g}, 7.3 \mathrm{mg} / \mathrm{g}$ 의 카페인을 함유하였 고, 브라질 버번은 약배전의 경우 $9.4 \mathrm{mg} / \mathrm{g}$ 에서 강배전의 경우 $11.1 \mathrm{mg} / \mathrm{g}$ 으로 증가하였으며, 인도네시아 만델링은 약배전의 경우 $9.0 \mathrm{mg} / \mathrm{g}$ 에서 $12.2 \mathrm{mg} / \mathrm{g}$ 으로 증가하여 배전 시 유의적인 차이로 증가하였다. 케냐 타투의 경우 약배전 시 $6.4 \mathrm{mg} / \mathrm{g}$ 의 카페인이 들어있었으며, 다른 품종과 마찬가 지로 배전이 진행됨에 따라 증가하는 경향을 보여 강배전에 서 $10.4 \mathrm{mg} / \mathrm{g}$ 의 함량을 나타냈다. 카페인 함량은 생두에서 강배전으로 진행됨에 따라 약간 증가하거나(20) 품종에 따 라 약간 감소했다는 보고(32)도 있었다. 카페인의 함량은 배전 자체에 의한 영향보다는 다른 성분들의 손실과 생두의 유의적인 중량 감소에 의한 상대적 증가로 보는 경우도 있으며(33), 카페인의 승화점 $\left(178^{\circ} \mathrm{C}\right)$ 이상에서 배전이 진행 되면 카페인의 손실이 있으나 배전공정 중 커피 내부 압력 의 상승으로 카페인의 승화점이 증가하여 매우 강한 강배전 이 아닌 경우, 비교적 카페인의 손실은 적다는 보고도 있다 (8). 또한 카페인 함량은 Rio-off-flavor(요오드와 같은 이취) 와는 음의 상관계가 있고, 높은 커피 품질(cup quality)을 갖는 커피의 카페인 함량이 높았다는 보고도 있다(34).

Table 4. Changes in total phenol, caffeine, and chlorogenic acid (CQA) contents in green and roasted coffee beans

\begin{tabular}{cccc}
\hline Sample & $\begin{array}{c}\text { Total phenol } \\
(\mathrm{mgGAE} / \mathrm{g})\end{array}$ & $\begin{array}{c}\text { Caffeine } \\
(\mathrm{mg} / \mathrm{g})\end{array}$ & $\begin{array}{c}\text { CQA } \\
(\mathrm{mg} / \mathrm{g})\end{array}$ \\
\hline Brazil & & & \\
Green bean & $21.3 \pm 0.27^{\mathrm{d} 1)}$ & $7.4 \pm 0.62^{\mathrm{c}}$ & $24.8 \pm 1.38^{\mathrm{a}}$ \\
Light & $36.2 \pm 2.09^{\mathrm{a}}$ & $9.4 \pm 0.03^{\mathrm{b}}$ & $16.9 \pm 0.38^{\mathrm{b}}$ \\
Medium & $27.5 \pm 0.81^{\mathrm{b}}$ & $10.8 \pm 0.35^{\mathrm{a}}$ & $9.8 \pm 0.04^{\mathrm{c}}$ \\
Dark & $25.0 \pm 0.05^{\mathrm{c}}$ & $11.1 \pm 0.24^{\mathrm{a}}$ & $5.6 \pm 0.007^{\mathrm{d}}$ \\
\hline Indonesia & & & \\
Green bean & $20.6 \pm 0.53^{\mathrm{d}}$ & $7.3 \pm 0.76^{\mathrm{c}}$ & $29.9 \pm 1.09^{\mathrm{a}}$ \\
Light & $29.6 \pm 0.10^{\mathrm{b}}$ & $9.0 \pm 0.06^{\mathrm{b}}$ & $19.9 \pm 0.23^{\mathrm{b}}$ \\
Medium & $32.1 \pm 0.87^{\mathrm{a}}$ & $9.1 \pm 0.17^{\mathrm{b}}$ & $14.1 \pm 0.01^{\mathrm{c}}$ \\
Dark & $26.9 \pm 0.23^{\mathrm{c}}$ & $12.2 \pm 0.02^{\mathrm{a}}$ & $4.1 \pm 0.02^{\mathrm{d}}$ \\
\hline Kenya & & & \\
Green bean & $23.1 \pm 0.24^{\mathrm{c}}$ & $7.3 \pm 0.56^{\mathrm{c}}$ & $26.7 \pm 1.51^{\mathrm{a}}$ \\
Light & $26.1 \pm 0.33^{\mathrm{a}}$ & $6.4 \pm 0.29^{\mathrm{d}}$ & $18.7 \pm 0.24^{\mathrm{b}}$ \\
Medium & $26.3 \pm 0.21^{\mathrm{a}}$ & $9.8 \pm 0.31^{\mathrm{b}}$ & $10.1 \pm 0.17^{\mathrm{c}}$ \\
Dark & $24.1 \pm 0.38^{\mathrm{b}}$ & $10.4 \pm 0.21^{\mathrm{a}}$ & $3.7 \pm 0.04^{\mathrm{d}}$ \\
\hline${ }^{\mathrm{b})}$ Mean \pm standard deviation $(\mathrm{n}=3)$. Means in a column with same superscript letters \\
are not significantly different $(\mathrm{p}<0.05)$. & &
\end{tabular}

\section{총 페놀함량}

페놀성 화합물은 식물이 환경적인 스트레스에 적응하기 위해 필요한 항산화 물질로 식물계에 널리 분포되어있는 2차 대사산물들이다. 커피의 페놀 화합물에는 $\mathrm{CGA}$ (클로로 
겐산)이 주된 성분이고 lignan, 토코페롤, 안토시아닌 등이 소량 존재하는 것으로 알려져 있다(35). 커피 생두와 배전 중 총 페놀함량 분석 결과는 Table 4과 같다. 총 페놀함량은 브라질 버번, 인도네시아 만델링, 케냐 타투의 생두에서 각각 $21.3,20.6,23.1 \mathrm{mgGAE} / \mathrm{g}$ 이었으며 약배전 시 브라질 과 케냐는 가장 높은 함량 $(36.2,26.1 \mathrm{mgGAE} / \mathrm{g})$ 을 보였다. 이는 약배전 시 총 페놀함량이 $42.4 \sim 55.0 \mathrm{mgGAE} / \mathrm{g}$ 으로 가장 많았다는 Hecimovic 등(16)과 Cho 등(7)의 보고와 일 치하는 결과였다. Cho 등(7)은 배전하지 않은 생두와 비교 하여 약배전한 원두에서 약 $49 \%$ 의 페놀이 더 검출되었으 며, 강배전했을 때에도 $73 \%$ 이상이 보존되었다고 보고하였 다. 본 연구결과에서도 강배전 시 총 페놀함량이 다소 감소 하는 경향을 보였으나 약배전의 70 82\%가 유지되어 비슷 한 결과를 나타냈다. Chism과 Haard(36)는 초기 배전 시 페놀 함량의 증가는 열가공에 의해 세포 구성분의 물리적 파괴가 일어나 생두 내부에 있던 항산화물질들이 방출되기 때문이며, 배전 정도가 강해짐에 따라 활성화되는 효소에 의해 페놀 함량이 감소된다고 보고하였다. 그러나 Tomaino 등(37)은 열가공 시 구조변화가 일어나는 페놀물질도 있으 나 새로운 항산화 화합물도 형성되어 총 페놀의 함량은 크게 변화하지 않으며, 커피의 전체적인 항산화능력 또한 크게 손실되지 않는 것으로 보고되었다.

\section{클로로겐산(5-caffeoylquinic acid) 함량}

커피의 페놀화합물 중 가장 많은 부분(약 $83 \%$ )을 차지하 는 클로로겐산은 커피 배전 중 쉽게 분해되어 커피의 맛과 향에 영향을 미치므로 커피 품질 평가에 중요한 성분이다 (8). 클로로겐산은 quinic acid에 caffeic acid가 ester결합을 하고 있는 상태인데, caffeoylquinic acid(CQA)와 feruloylquinic $\operatorname{acid}(\mathrm{FQA})$ 그리고 dicaffeoylquinic acid(diCQA)와 같은 3 개 의 이성질체가 있으며(38), 이중 5-CQA가 아라비카 품종에 서는 전체 클로로겐산의 $66 \%$, 로부스타 품종에서는 $56 \%$ 를 차지한다고 보고되었다(39).

클로로겐산의 한 종류인 5-CQA는 커피에서 polyphenol oxidase(PPO)의 기질이 되어 원두의 갈색화에 원인이 되는 o-quinones을 생성하는 것으로 밝혀졌으며(40), $\mathrm{PPO}$ 의 작 용은 또한 커피콩 세포막의 구조적 변화를 유발시켜 Rio-off-flavor의 원인이 될 수 있다고 한다(41). 배전 중 $\mathrm{CQA}$ 의 함량 분석 결과는 Table 4 에 보여주는 바와 같이, 세 품종 모두 생두에서 가장 높은 함량을 나타낸 $\mathrm{CQA}$ 는 배전이 진행됨에 따라 감소하여 강배전 시 브라질 버번 $77 \%$, 인도네시아 만델링 $86 \%$, 케냐 타투에서 $86 \%$ 가 손실 되었다. 이는 강배전 시 CQA가 $93 \%$ 의 손실되었다는 Farah 등(35)의 연구 결과와 강배전까지 진행되는 동안에 $\mathrm{CQA}$ 의 83-93.4\%가 손실되었다는 Tfouni 등(20)의 연구결과와 비 슷하였다. 또한 아라비카 생두 $13.57 \mathrm{mg} / \mathrm{g}$, 약배전 9.70 $\mathrm{mg} / \mathrm{g}$, 중배전 $6.77 \mathrm{mg} / \mathrm{g}$ 강배전 $4.79 \mathrm{mg} / \mathrm{g}$ 의 CQA 함량을
보고한 Cho 등(7)의 연구결과와도 유사한 경향을 보였다. 클로로겐산의 일부는 배전 중 quinolactone이나 melanoidin 으로 전환되어 원두의 색상에 영향을 미치는 것으로 보고되 었다(42). Perrone 등(43)은 $\mathrm{CQA}$ 의 감소가 배전 초기에는 isomerization 후기에는 epimerization, latonization, degradation 으로 인한 C-C 공유결합의 열분해 결과에 의한 것이라고 하였다.

\section{라디칼 소거활성 변화}

브라질, 인도네시아, 케냐 커피의 배전 정도별 항산화력 을 비교하기 위하여 $\mathrm{DPPH}$ 와 $\mathrm{ABTS}$ 라디칼 소거활성을 측 정한 결과는 Fig. 1 과 같다. $\mathrm{DPPH}$ 와 $\mathrm{ABTS}$ 모두 라디칼의 환원력을 측정하는 실험으로 원리는 비슷하지만 ABTS는 극성, 비극성 물질에서 확인할 수 있으며, DPPH는 비극성 물질에서만 확인할 수 있다는 점에서 차이가 있다(7). 모든 시료에서 생두에 비해 배전 후 원두의 $\mathrm{ABTS}$ 와 DPPH 라디 칼 소거활성이 높았으며, 배전 정도가 높아짐에 따라 케냐 의 ABTS 값을 제외하고는 소거활성이 감소하였다. 약배전 에서 강배전으로 진행됨에 따라 DPPH 소거능은 브라질 버번은 $36 \%$, 인도네시아 만델링은 $51 \%$, 케냐의 타투는 $42 \%$ 의 감소를 나타냈다. Cho 등(7)은 커피의 플라보노이드 (flavonoids)는 열처리에 의해 쉽게 파괴되어 강배전할 경우 에는 $23 \%$ 의 플라보노이드만 남아있게 된다고 보고하였다.
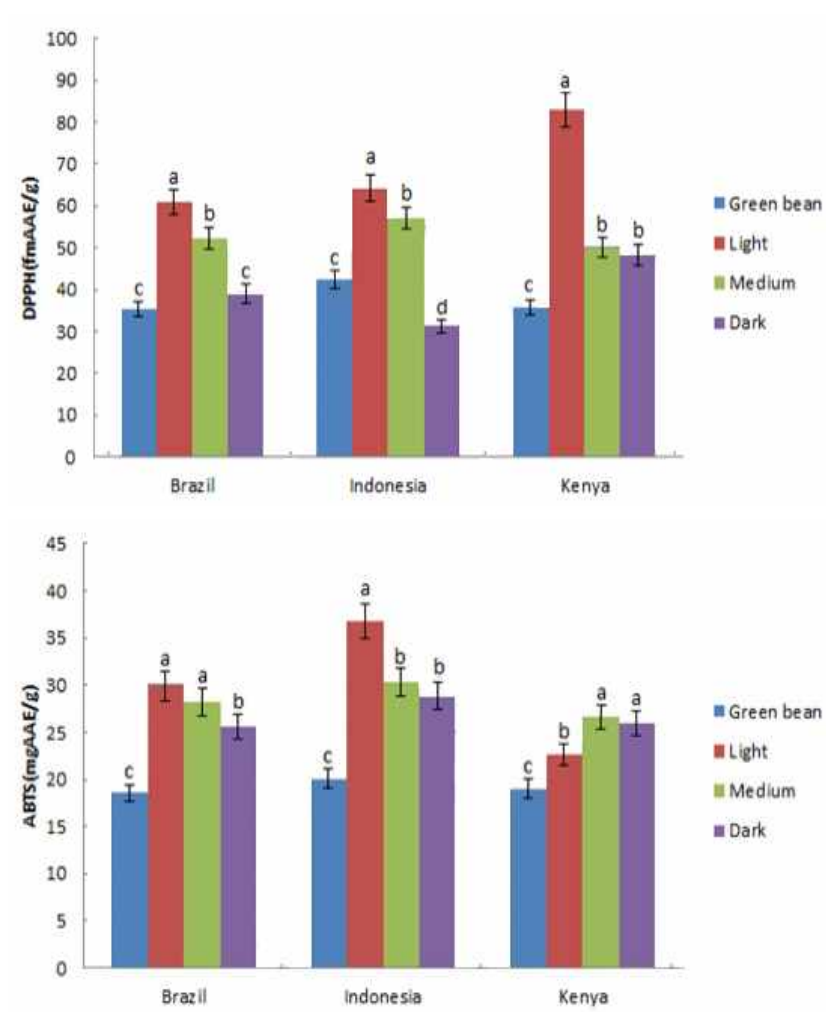

Fig. 1. Radical scavenging activities of coffee extracts measured by DPPH and ABTS.

Results are expressed as mean \pm SD ( $n=3$ ). Means with same letters are not significantly different at $\mathrm{p}<0.05$. 
따라서 커피의 항산화력을 높이기 위해서는 약배전이 요구 되며 커피의 항산화력은 배전시간에 반비례한다고 보고하 였다. 본 연구에서도 생두보다 약배전한 원두의 항산화력 이 높았으며, 배전 정도가 증가함에 따라 항산화력이 감소 하여 Cho 등(7)의 연구 결과와 같은 경향을 나타내었다.

\section{전자코 분석}

브라질, 인도네시아, 케냐 커피의 향기 패턴을 알아보기 위해 각 시료 간에 의미 있는 차이가 있는 10 개의 피크를 선정하여 주성분 분석(PCA)한 결과를 Fig. 2에 나타내었다. $\mathrm{PC} 1$ 의 편차는 $74.74 \% . \mathrm{PC} 2$ 의 편차는 $20.76 \%$ 를 나타내 $\mathrm{PC} 1$ 에서 시료간의 차별성이 뚜렷하였다. 전자코 분석 결과 향 기의 차이는 그래프 상 거리와 방향의 근접성에 따라 판단 되는데 가까운 점들은 서로 유사한 향기를 가지고 있으며 반대로 서로 다른 방향과 거리가 먼 위치의 점들은 유사성 이 없는 향기로 나타난다. 시료간의 차별성이 큰 제 1 주성 분 값을 비교할 때 배전이 진행됨에 따라 브라질 버번, 케냐 타투 및 인도네시아 만델링 시료 모두 향기패턴의 차이를 확연히 보이며 배전이 진행됨에 따라 제 1 주성분 값이 작아지는 것을 볼 수 있었다. 이러한 결과들은 커피 생두의 품종에 따른 향기패턴 분석이 가능하고, 추가적으로 배전 시간에 따라서도 향기패턴이 달라짐을 보여준다. 이는 배 전이 진행됨에 따라 커피의 향기성분이 달라지기 때문에 커피 생두의 배전과정 중에 이러한 향기성분의 변화를 전자 코 분석 방법을 통하여 구분할 수 있음을 보여준다.

\section{요 약}

아라비카 커피 생두 3종(브라질 버번, 인도네시아 만델 링, 케냐 타투)을 배전 온도 $181 \sim 215^{\circ} \mathrm{C}$ 의 범위에서 $8.15 ~ 11.83$ 분의 조건에서 약배전, 중배전, 강배전으로 배전 하여 물리적 특성, 이화학적 성질, 항산화력 등을 조사하였 다. 배전 온도가 증가함에 따라 무게와 밀도가 감소하였고, $\mathrm{L}^{*}, \mathrm{a}^{\star}, \mathrm{b}^{\star}$ 값이 감소하였다. 총 페놀함량은 생두보다는 배전 후의 원두에서 더 높았으며, 약배전과 중배전에서 가장 높 았다. 카페인 함량은 강배전한 시료에서 가장 높았다. 클로 로겐산은 생두에서 가장 높았으며, 배전의 강도가 강해짐 에 따라 감소하였다. $\mathrm{ABTS}$ 와 DPPH 라디칼 소거능은 생두 보다는 배전 후의 원두에서 더 높았으며, 배전의 강도가 강해짐에 따라 감소하였다. 따라서 항산화력을 유지하기 위해서는 지나치게 높은 온도에서 배전하는 것보다는 낮은 온도에서 약배전하는 것이 바람직한 것으로 사료된다. GC 를 기초로 한 전자코를 활용하여 커피의 향기패턴을 분석한 결과 품종과 배전정도에 따른 향기패턴의 차이를 잘 구분할 수 있었다.

\section{감사의 글}

본 연구는 중소기업청에서 지원하는 2013년도 산학연협 력 기술개발사업(No. C0123466)의 연구수행으로 인한 결 과물임을 밝힙니다.

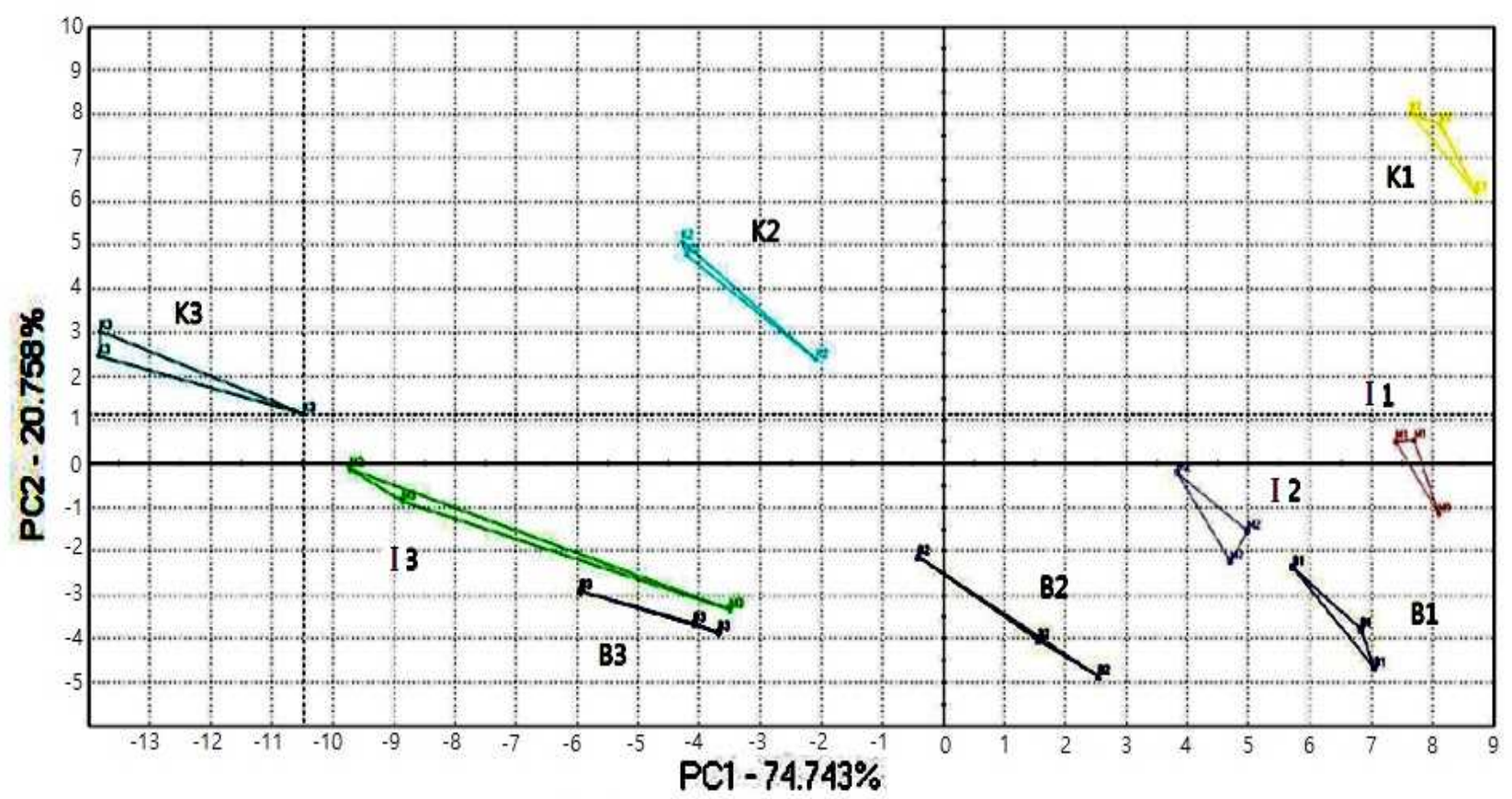

Fig. 2. Electronic nose data for flavor patterns of roasted coffee.

K1, Kenya light; K2, Kenya medium; K3, Kenya dark; I1, Indonesia light; I2, Indonesia medium; I3, Indonesia dark; B1, Brazil light; B2, Brazil medium; B3, Brazil dark. 


\section{References}

1. Smith AW (1985) Introduction. In: Coffee. Volume 1: Chemistry. Clarke RJ, Macrae R(Editors), Elsevier Applied Science, London, England, p 1-41

2. Sivetz M, Fonte E (1963) Coffee Processing Technology. Avi Publishing Co, Westport, Connecticut, USA, p 320-349

3. Baik HJ, Ko YS (1996) Studies on the aroma components of roasted and ground coffee. Korean J Food Sci Technol, $28,15-18$

4. Czerny M, Grosch W (2000) Potent odorants of raw Arabica coffee : their changes during roasting. J Agric Food Chem, 48, 868-872

5. Baggenstoss J, Poisson J, Kaegi R, Perren R, Escher F (2008) Coffee roasting and aroma formation : application of different time-temperature conditions. J Agric Food Chem, 56, 5836-5846

6. Mayer F, Czerny M, Grosch W (1999) Influence of provenance and roast degree on the composition of potent odorants in Arabica coffees. Eur Food Res Technol, 209, 242-250

7. Cho AR, Park KW, Kim KM, Kim SY, Han J (2014) Influence of roasting conditions on the antioxidant characteristics of Colombian coffee (Coffea arabica L.) beans. J Food Biochem, 38, 271-280

8. Kim KJ, Park SK (2006) Changes in major chemical constituents of green coffee beans during the roasting. Korean J Food Sci Technol, 38, 153-158

9. Karakaya S, El SN, Tas AA (2001) Antioxidant activity of some foods containing phenolic compounds. Int J Food Sci Nutr, 52, 501-508

10. Namba T, Matsuse T (2002) A historical study of coffee in Japanese and Asian countries : forcusing the medicinal uses in Asian traditional medicines. J Japan Hist Pharm, 37, 65-75

11. Yukawa GS, Mune M, Otani H, Tone Y, Liang XM, Iwahashi H, Sakamoto W (2004) Effects of coffee consumption on oxidative susceptibility of low-density lipoproteins and serum lipid levels in humans. Biochem, 69, 70-74

12. Naidu MM, Sulochanamma G, Sampathu SR, Srinivas P (2008) Studies on extraction and antioxidant potential of green coffee. Food Chem, 107, 377-384

13. Suh YS, Lee SH, Shang Y, Yoon JR, Lee WJ (2014) Changes in antioxidant activities and flavor patterns of Coffea arabica beans during roasting. Korean J Food
Preserv, 21, 224-230

14. Loufti A, Coradeschi S, Mani GK, Shankar P (2014) Elecronic noses for food industry, a review. J Food Eng, 144, 103-111

15. AOAC (1995) Official Method of Analysis. Association of Official Analytical Chemists, Washington DC, p 1137-1139

16. Hecimovic H, Belscak-Cvitanovic A, Horzic D, Komess D (2011) Comparative study of polyphenols and caffeine in different coffee varieties affected by the degree of roasting. Food Chem, 129, 991-1000

17. Blois MS (1958) Antioxidant determination by the use of a stable free radical. Nature, 181, 1199-2000

18. Re R, Pellegrini N, Proteggente A, Pannala A, Yang M, Rice-Evans C (1999) Antioxidant activity applying an improved ABTS radical cation decolorization assay. Free Radic Biol Med, 26, 1231-1237

19. Kim HK, Hwang SY, Yoon SB, Chun DS, Kong SK, Kang KO (2007) A study of the characteristics of different coffee beans by roasting and extracting condition. Korean J Food Nutr, 20, 14-19

20. Tfouni ASV, Serrate CS, Carreiro LB, Camargo MCR, Teles CRA, Cipolli KMVAB, Furlani RPZ (2012) Effect of roasting on chlorogenic acids, caffeine and polycyclic aromatic hydrocarbons levels in two Coffea cultivas : Coffea arabica cv. Catuai Amarelo IAC-62 and Coffea canephora cv. Apoata IAC-2258. Int Food Sci Technol, 47, 406-415

21. ICO (2005) OTA risk management : Guidelines for green coffee buying. Report of the quality committee, International Coffee Organization, ED-1939/05

22. Alessandrini L, Romani S, Pinnavaia G, Rosa MD (2008) Near infrared spectroscopy : an analytical tool to predict coffee roasting degree. Anal Chim Acta, 625, 95-102

23. Oosterveld A, Harmsen JS, Voragen HA (2003) Extraction and characterization of polysaccharides from green and roasted coffee beans. Carbohyd Polym, 52, 258-296

24. Franca AS, Oliveira LS, Oliveira RCS, Agresiti PCM, Augusti R, Mendonca JCF, Silva XA (2009) A preliminary evaluation of the effect of processing temperature on coffee roasting degree assessment. J Food Eng, 92, 345-352

25. Pittia P, Dalla Rosa M, Lerici CR (2001) Textural changes of coffee beans as affected by roasting conditions. LWT-Food Sci Technol, 34, 168-175

26. Jokanovic MR, Dzinic NR, Cvetkovic BR, Grujic S, 
Odzakovic B (2012) Changes of physical properties of coffee beans during roasting. Acta Periodica Technologica, 43, 21-31

27. Choi YM (2009) Sensory characteristics of coffee in relation to the processing and classification of green coffee. MS Thesis. Kyung Hee University, Seoul, Korea

28. Illy A, Viani R (2004) Espresso Coffee : The Science of Quality. 2nd ed, Academic Press, San Diego, CA, USA, p 91-95

29. Sivetz M, Desrosier NW (1979) Coffee Technology. AVI Publishing Co. Westport, Connecticut, USA, p 415-565

30. Park SJ, Moon SW, Kim EJ, Kang BS (2011) Optimization of roasting conditions for coffee beans by response surface methodology. Korean J Food Preserv, $18,178-183$

31. Borrelli RC, Visconti A, Mennella C, Anese M, Fogliano V (2002) Chemical characterization and antioxidant properties of coffee melanoidins. J Agric Food Chem, 50, 6527-6533

32. Casal S, Oliveira MB, Ferreira MA (2000) HPLC/diodearray applied to the thermal degradation of trigonelline, nicotinic acid and caffeine in coffee. Food Chem, 68, 481-485

33. Macrae R (1985) Nitrogenous compounds. In: Coffee, Volume 1: Chemistry. Clarke RJ, Macrae R(Editors), Elsevier Applied Science, London, England, p 115-152

34. Farah A, Monteiro MC, Calado V, Franca AS, Trugo LC (2006) Correlation between cup quality and chemical attributes of Brazilian coffee. Food Chem, 98, 371-380
35. Farah A, Donangelo CM (2006) Phenolic compound in coffee. Braz J Plant Physiol, 18, 23-26

36. Chism GW, Haard NF (1996) Characteristics of edible plant tissues. In: Food Chemistry. Fennema OR(Editor), Dekker, NY, USA, p 944-1007

37. Tomaino A, Cimino F, Zimbalatti V, Venuti V, Sulfaro V, De Pasqual A, Saija A (2005) Influence of heating on antioxidant activity and the chemical composition of some spice essential oils. Food Chem, 89, 549-554

38. Clifford MN, Wight J (1976) The measurement of feruloylquinic acids and caffeoylquinic acids in coffee beans. J Sci Food Agric, 27, 73-84

39. Trugo LC, Macrae R (1984) Chrorogenic acid composition of instant coffee. Analyst, 109, 263-266

40. Mazzafera P, Robinson SP (2000) Characterization of polyphenol oxidase in coffee. Phytochem, 55, 285-296

41. Amorium HV, Cruz AR, St. Angelo AJ, Dias RM, Mello, M, Teixeira AA, Gutierrez LE, Ory RL (1977) Biochemical, physical and organoleptical changes during raw coffee quality deterioration. Paper presented at the 8th International Coffee Symposium, November 28-December 3, Abidjan, Côte d'Ivoire

42. Kim JY, Han YS (2009) Influence of roasting time on antimicrobial and antioxidative effects of coffee extract. Korean J Food Cookery Sci, 25, 496-505

43. Perrone D, Farah A, Donangelo CM, de Paulis T, Martin PR (2008) Comprehensive analysis of major and minor chlorogenic acids and lactones in economically relevant Brazilian coffee cultivars. Food Chem, 106, 859-86 